\title{
ASSESSING THE FEASIBILITY OF THE BDq METHOD FOR THE SUSTAINABLE MANAGEMENT OF THE CAATINGA ${ }^{1}$
}

\author{
JOÃO HENRIQUE DO NASCIMENTO NETO ${ }^{2 *}$, ALAN CAUÊ DE HOLANDA ${ }^{3}$, JADSON COELHO DE ABREU ${ }^{4}$
}

\begin{abstract}
The BDq method is based on the concept of a balanced forest, in which the current growth can be periodically removed while maintaining the initial diameter distribution of the forest. This study aimed to analyze the technical feasibility in the application of three cutting intensities and six scenarios in sustainably managed Caatinga vegetation. The study was carried out at the Fazendas Baixa da Oiticica, Rancho da Velha, and Tabuleiro de Dentro, located in the municipality of Upanema (state of Rio Grande do Norte), with an area of around 343 hectares. We established 11 plots of $20 \times 20 \mathrm{~m}$ and measured all individuals with a circumference at breast height $(\mathrm{CBH}) \geq 6 \mathrm{~cm}$ within these plots. The individuals were identified in the field, and the APG IV classification system was adopted to organize the list of scientific names and families. Three management alternatives were proposed, namely reducing $40 \%$ (Scenario 1), 50\% (Scenario 2), and 60\% (Scenario 3) of the basal area and the actual volume for the application of the BDq method. In total, 1,680 individuals distributed in 10 families, 18 species, 16 genera, and 7 diameter classes were inventoried. Considering rational, sustainable harvesting, and following the theoretical rules of dynamic processes, cuts may not be carried out in larger diameter class centers $(22.45,27.45$, and $32.45 \mathrm{~cm})$. Scenario 3 showed the most effective results, as it allows the harvesting of the highest number of individuals and provides a greater economic return.
\end{abstract}

Keywords: De Liocourt quotient. Diametric distribution. Dry forest.

\section{USO DO MÉTODO BDq EM UMA ÁREA DE CAATINGA SUBMETIDA AO MANEJO FLORESTAL}

RESUMO - O método BDq está baseado no conceito de floresta balanceada em que o crescimento corrente pode ser removido periodicamente enquanto se mantêm a distribuição de diâmetros inicial da floresta. $\mathrm{O}$ trabalho teve por objetivo analisar a viabilidade técnica na aplicação de três intensidades de corte e seis cenários em vegetação da Caatinga submetida ao manejo florestal sustentável. O trabalho foi desenvolvido na Fazendas Baixa da Oiticica, Rancho da Velha e Tabuleiro de Dentro, situados no município de Upanema-RN, com área de 343,0472 hectares submetidas ao manejo. No processo amostral foram alocadas 11 parcelas de 20 $\mathrm{m} \times 20 \mathrm{~m}$. Foram mensurados todos os indivíduos com circunferência a altura do peito (CAP) $\geq 6 \mathrm{~cm}$. Os indivíduos foram identificados in loco, sendo adotado o sistema de classificação APG IV para organização da lista dos nomes científicos e famílias. Para a aplicação do método BDq, foram propostas três alternativas de manejo, com 40\% (Cenário 1), 50\% (Cenário 2) e 60\% (Cenário 3) de redução da área basal e volume real. Inventariou-se 1.680 indivíduos distribuídos em 10 famílias, 18 espécies, 16 gêneros e sete classes de diâmetro. Levando em consideração a exploração racional, sustentável e, seguindo os preceitos teóricos dos processos dinâmicos, não pode realiza-se cortes nos centros de classes de maiores diâmetro $(22,45 ; 27,45$ e $32,45 \mathrm{~cm})$ e, a combinação que apresentou os resultados mais efetivos foi o cenário 3 , pois possibilita a exploração de um número maior de indivíduos conferindo maiores rendimentos econômicos.

Palavras-chave: Quociente De Liocourt. Distribuição diamétrica. Floresta seca.

\footnotetext{
${ }^{*}$ Corresponding author

${ }^{1}$ Received for publication in $01 / 23 / 2020$; accepted in $04 / 23 / 2020$.

Paper extracted from the da dissertation of the first author

${ }^{2}$ Specialized Academic Unit in Agricultural Sciences, Universidade Federal do Rio Grande do Norte, Macaíba, RN, Brazil; joao_1601@hotmail.com - ORCID: 0000-0003-1085-1952.

${ }^{3}$ Department of Agricultural and Forestry Sciences, Universidade Federal Rural do Semi-Árido, Mossoró, RN, Brazil; alan.holanda@ufersa.edu.br-ORCID: 0000-0003-1408-0075.

${ }^{4}$ Forest Engineering Collegiate, Universidade do Estado do Amapá, Macapá, AP, Brazil; jadson.abreu@ueap.edu.br - ORCID: 0000-00019273-7533.
} 


\section{INTRODUCTION}

The Caatinga biome is the ecosystem with the largest vegetation coverage in northeastern Brazil. Its geoecological area comprehends approximately $844,453 \mathrm{~km}^{2}$, under subequatorial latitudes between $2^{\circ} 45^{\prime}$ and $17^{\circ} 21^{\prime}$ S. Its area accounts for approximately $70 \%$ of the northeastern region and for $11 \%$ of the Brazilian territory and is included in the drought polygon (ALVES, 2007). Although it has suffered from substantial deforestation, it contributes to the economy of the northeastern region through the provision of environmental services, albeit only under sustainable use (SOTERO et al., 2013).

Sustainable use of the Caatinga is a propagator of the local economy, reducing the rate of deforestation and, consequently, preserving the biome and its essential environmental functions (ARAÚJO, 2015). The sustainable use of forest resources is achieved through reasonable forest management, aimed at minimizing the ecological impacts of harvesting and increasing the regenerative capacity of the forest (VERÍSSIMO; PEREIRA, 2015).

The BDq (basal-area-diameter- $q$-ratio) is one of the management tools used in forest regulation methods. It promotes actions for natural regeneration and establishes criteria for the removal of forest trees and harvest. This approach allows the least impact on the remaining population to obtain a more sustainable production (SOUZA; SOUZA, 2005; SOUZA; SOARES, 2013).

The BDq method is based on the concept of the balanced forest, and its application in selective logging leads to a remaining stock that promotes the maintenance of the forest diametric structure (SOUZA; SOARES, 2013). The BDq considers the different size classes (e.g., diameter distribution), which makes it an essential tool in decision making and management planning for a given area. The diametric distribution allows to characterize a forest typology and to examine the history of the species in the area, the number of trees to be harvested, natural regeneration, and the sustainability of the species after harvest (LIMA et al., 2014; RODE et al., 2015, SILVA et al., 2018).

However, few studies have applied the BDq for the Caatinga, and in this context, we analyzed the technical feasibility of the method, considering three logging intensities and six scenarios in the Caatinga biome against he background of sustainable forest management.

\section{MATERIAL AND METHODS}

Study area
The study was carried out in the rural properties Fazendas Baixa da Oiticica, Rancho da Velha, and Tabuleiro de Dentro, located in the municipality of Upanema, state of Rio Grande do Norte. The area under forest management covers 343.0472 hectares, situated between the geographical coordinates $5^{\circ} 29^{\prime} 58.2^{\prime \prime} \mathrm{S}$ and $37^{\circ} 20$ '28.8” W.

The climate is characterized as BSh (warm and semi-arid) according to the Köppen classification, with 7 to 9 dry months and an irregular rainy season from February to July (ALVARES et al., 2013). Mean annual rainfall is $670 \mathrm{~mm}$, with an annual water deficit of $1,000 \mathrm{~mm}$ and mean temperatures above $28^{\circ} \mathrm{C}$ throughout the year (IBGE, 2002).

The vegetation comprises Arboreal Steppic Savannah or hyperxerophilic Caatinga, with a sparse canopy with a height of $3 \mathrm{~m}$, an arboreal stratum formed by low trees with clumps or thorns, and a periodic grassy-woody stratum with several cacti (IBGE, 2004).

The areas submitted to the Forest Management Plan have a long history of disturbance (for at least 30 years) since they are close to an industrial region where limestone and firewood as raw material are combined for the production of quicklime.

\section{Data collection}

Eleven sample units of $20 \times 20 \mathrm{~m}$ were randomly allocated in the forest inventory carried out for data collection (BRASIL, 2005). All woody individuals with a circumference at breast height $(\mathrm{CBH}) \geq 6.0 \mathrm{~cm}$ were measured within the sample units. The sampling curve was used to verify the sampling sufficiency of the forest inventory, which indicates the optimal size of the sample area by the accumulated frequency of species per plot.

Each stem was considered an individual to predict volume, with the following criteria: a) the trees or shrubs with a bifurcation between ground level and a height of $30 \mathrm{~cm}$ were considered distinct individuals (BRASIL, 2005); b) the trees or shrubs with a bifurcation above $30 \mathrm{~cm}$ from the ground level were considered as a single individual, and the different CBH's of the measured stems were homogenized by the formula of the equivalent circumferences: $C B H_{i}=\sqrt{\sum C B H_{n}^{2}}$. The diametric distribution was calculated based on diameter at breast height ( $\mathrm{DBH}$, obtained from the $\mathrm{CBH})$, considering an amplitude of $5 \mathrm{~cm}$.

The circumferences were transformed into diameter, and the basal area was subsequently calculated using the following formula:

$$
\mathrm{G}=\frac{\pi}{40000} \sum_{i=1}^{n} D B H^{2},
$$

where $\mathrm{G}=$ basal area; $\pi=$ "pi" (3.1416...); DBH $=$ 
diameter at breast height (in centimeters); 40,000= quadratic conversion factor from centimeters to meters (from DBH).

The total volume was calculated considering the DBH (with bark) of the measured trees and shrubs, using the following equations:

$$
\begin{aligned}
& V C_{c / c}=\frac{\pi \cdot(D B H)^{2} \cdot H T}{40000} \\
& V R=V C_{c / c} \cdot f f \\
& V t=\sum_{i=1}^{n} V R,
\end{aligned}
$$

where $\mathrm{VCc} / \mathrm{c}=$ cylindrical volume of the individual tree with bark (in cubic meters $-\mathrm{m}^{3}$ ); HT = total height of the tree (in meters); VR = actual volume (in cubic meters $\left.-\mathrm{m}^{3}\right)$; ff $=$ form factor $(0.9$, dimensionless); $\mathrm{Vt}=$ total volume of the sample (in cubic meters - $\mathrm{m}^{3}$ ) (ZAKIA; PAREYN; RIEGELHAUPT, 1988).

The species were identified in loco by their dendrological aspects (shape of the canopy, foliage, bark, and stem), popular names, and, when possible, by collecting botanical material for herborization (flowers and fruits) and subsequent identification to confirm their scientific names obtained from the literature. The Angiosperm Phylogeny Group IV system (2016) was adopted to organize the list of scientific names and species families.

Estimates of individuals' frequency by diameter class and the De Liocourt Quotient "q"

The BDq selection method, reported by Meyer (1952) and employed by Campos, Ribeiro and Couto (1983), was applied to obtain a balanced forest structure. The diameter distribution model (MEYER, 1952) was adjusted to estimate the number of trees by diameter class, as mentioned by Campos and Leite (2013):

$$
Y j=e^{\beta_{0}+\beta_{1} \cdot D j} \cdot \varepsilon_{j},
$$

where $\mathrm{Yj}=$ number of trees per hectare; $\mathrm{e}=$ base of the Neperian logarithm; $\beta_{0}$ and $\beta_{1}=$ parameters to be estimated; $\mathrm{Dj}=\mathrm{DBH}$ class center, in $\mathrm{cm} ; \varepsilon j=$ random error.

The different estimated values of $\beta_{0}$ and $\beta_{1}$ provide different diametric structures, obtained by the method of the ordinary least squares.

While $\beta_{0}$ indicates the relative density of the population for a given diameter class, $\beta_{1}$ indicates the rate of decrease in the number of individuals per class (CAMPOS; LEITE, 2013). The De Liocourt quotient (q) was calculated using the fitted model, according to the following equation:

$$
q=\frac{e^{\left(\beta_{0}+\beta_{1} \mathrm{D}_{i}\right)}}{e^{\left(\beta_{0}+\beta_{1} \mathrm{D}_{i+1}\right)}}
$$

where $\mathrm{q}=$ ratio between the frequency of any diameter class by the immediate frequency above; D $=\mathrm{DBH}$ class center $(\mathrm{cm})$.

After obtaining the quotient " $\mathrm{q}$ ", the parameters $\beta_{0}$ and $\beta_{1}$ were calculated with the following equations:

$$
\begin{aligned}
\beta_{1} & =\frac{\operatorname{In}(q)}{D_{j}-D_{j+1}} \\
\beta_{0} & =\ln \left(\frac{40000 . G}{\pi \cdot \sum_{j=1}^{J} D^{2} j \cdot e^{\beta 1 . D j}}\right),
\end{aligned}
$$

where $\mathrm{e}=$ exponential; $\beta_{0}$ and $\beta_{1}=$ parameters to be estimated; $\mathrm{G}=$ remaining basal area; $\mathrm{Dj}=\mathrm{DBH}$ class center, in $\mathrm{cm} ; \mathrm{G}=$ remaining basal area; $\ln =$ Neperian logarithm; $\pi=$ "pi" (3.1416...); $\mathrm{Dj}+1=$ center of the diameter class immediately above.

Three scenarios were simulated using the $\mathrm{BDq}$ method for the analysis: Scenario 1 (S1), reducing $40 \%$, Scenario 2 (S2), reducing 50\%, and Scenario 3 (S3), reducing $60 \%$ of the observed basal area and volume in the population. Data tabulation, processing, and analysis were performed using the Microsoft Office Excel software.

\section{RESULTS AND DISCUSSION}

The sampling sufficiency (Figure 1) shown in the collecting curve indicates that the curve stabilizes from the eighth plot $\left(3,200 \mathrm{~m}^{2}\right)$ onwards. This finding suggests that the minimum floristic representation area was reached, leading to stagnation in the number of species found. Thus, the sampling sufficiency proved to be satisfactory for the study area, since it reached the minimum number of plots to adequately characterize the floristic composition. 


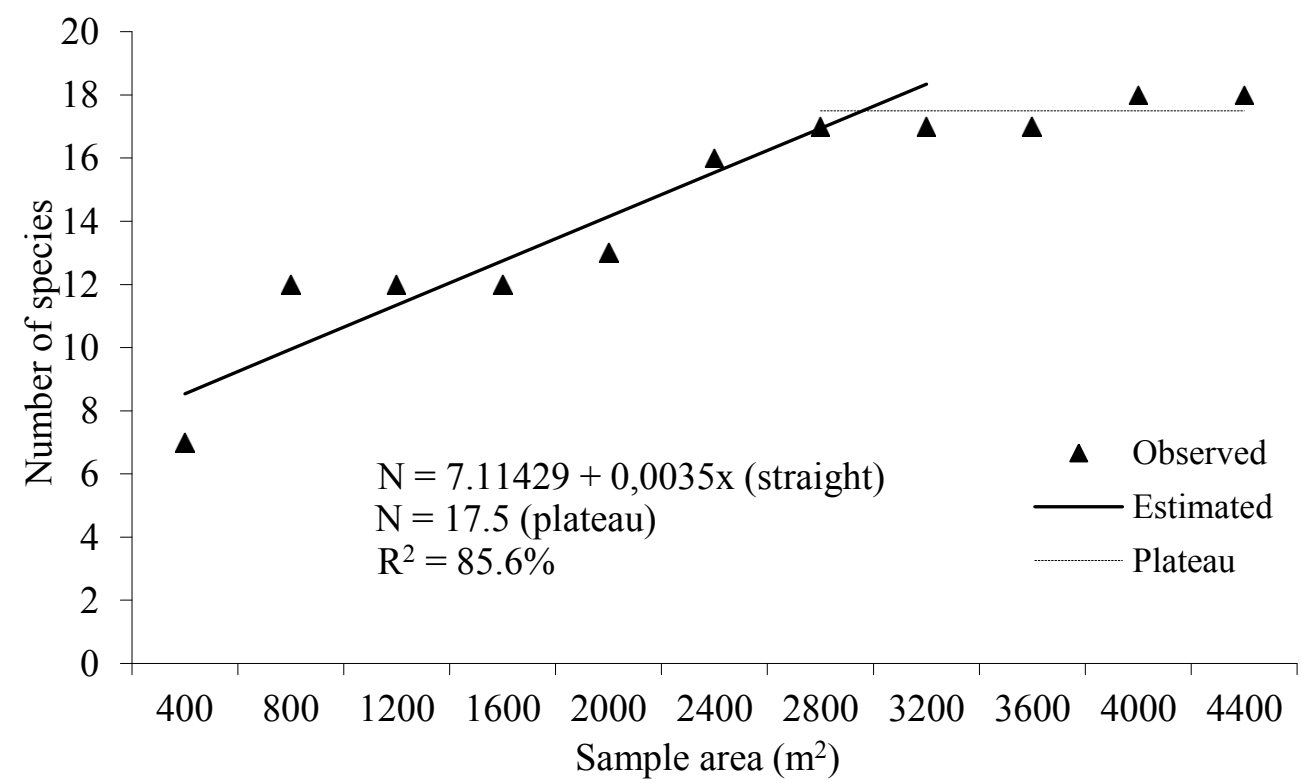

Figure 1. Graphical representation of the sampling sufficiency of the species inventoried in a fragment of the Caatinga, in the municipality of Upanema, state of Rio Grande do Norte.

This preliminary survey is essential to determine whether the established sample size is sufficient to represent the community. As mentioned by Schilling and Batista (2008), sample representativeness indicates whether the floristic composition and the density of individuals per species are satisfactory. In this study, 1,680 woody individuals were sampled, with representatives from 10 botanical families, 18 species, and 16 genera. The family Fabaceae had the highest number of species (9) of all families in the area. The families Anacardiaceae, Boraginaceae, Brassicaceae, Burseraceae, Combretaceae, Euphorbiaceae, Malvaceae, and Oleaceae were represented by only one species, corresponding to $46.74 \%$ of all sampled individuals. The species Combretum leprosum ("mofumbo") was the most prominent one, presenting the highest number of individuals (406). The species Amburana cearenses and Bauhinia cheilantha were recorded in all plots. Among all measured individuals, 138 were dead (Table 1).

The number of species inventoried is low when compared to other phytophysiognomies in Brazil, for instance, Ombrophilous Forests, Seasonal Forests, and Savannas. However, this is almost a standard for the semi-arid northeast (Estepic Savannah) due to the long history of disturbance or degradation, dating back to colonial times.

As highlighted by Medeiros et al. (2018), the composition and structure of the vegetation vary significantly on a regional scale (micro and macro scales) due to abiotic (e.g., soil, altitude, and rainfall) and anthropogenic factors. These authors found 304 individuals from 8 families and 13 species in a fragment of the Caatinga in the municipality of São Mamede, state of Paraíba. Marangon et al. (2013) inventoried 1,227 individuals from 18 families in a conserved area in the municipality of Floresta, state of Pernambuco. Similarly, Lemos and Meguro (2015) estimated 6,014 individuals (ha) from 20 families in the state of Aiuaba-Ceará, while Leite et al. (2015) reported 3,069 individuals from 24 families in the region of Teixeira, state of Paraíba.

Therefore, floristic and phytosociological surveys show a high variability in the composition and density of individuals from different environments in the Caatinga, as noted by Amorim, Sampaio and Araújo (2005). The authors found considerable physiognomic variation and changes on a local scale in the Caatinga, which are easily recognizable and generally linked to easily identifiable environmental changes.

Santos et al. (2017) observed that the families Fabaceae and Euphorbiaceae were the most abundant ones, both in the number of species and individuals, in a study carried out in different areas of the Caatinga in the state of Paraíba. These families cover most of the woody species of the Caatinga biome (CALIXTO JÚNIOR; DRUMOND, 2014), which has also been mentioned by Leite et al. (2015) and Holanda et al. (2015). 
Table 1. List of inventoried woody individuals in the forest management area.

\begin{tabular}{|c|c|c|c|}
\hline \multirow{2}{*}{ Family/Species } & \multirow{2}{*}{ General name } & \multicolumn{2}{|r|}{ Individuals } \\
\hline & & $\overline{\mathrm{N}^{\circ} \mathrm{I}}$ & Plots \\
\hline \multicolumn{4}{|l|}{ Anacardiaceae } \\
\hline Myracrodruon urundeuva M. Allemão & Aroeira & 7 & $5,6,8$ \\
\hline \multicolumn{4}{|l|}{ Apocynaceae } \\
\hline Aspidosperma pyrifolium (Mart.) & Pereiro & 196 & $1,2,4,8,11$ \\
\hline \multicolumn{4}{|l|}{ Boraginaceae } \\
\hline Cordia oncocalyx Allemão & Pau branco & 5 & 6,8 \\
\hline \multicolumn{4}{|l|}{ Brassicaceae } \\
\hline Capparis hastata (Jacq.) & Feijão bravo & 5 & 10 \\
\hline \multicolumn{4}{|l|}{ Burseraceae } \\
\hline Commiphora leptophloeos (Mart.) J.B.Gillett & Imburana de Cambão & 43 & $1,4,6,7,8,9,10,11$ \\
\hline \multicolumn{4}{|l|}{ Combretaceae } \\
\hline Combretum leprosum (Mart.) & Mofumbo & 406 & $2,3,4,5,6,7,8,9,10,11$ \\
\hline \multicolumn{4}{|l|}{ Euphorbiaceae } \\
\hline \multicolumn{4}{|l|}{ Fabaceae } \\
\hline Amburana cearensis (F. Allemão) A. C. Mith & Cumaru & 9 & $1,2,3,4,5,6,7,8,9,10,11$ \\
\hline $\begin{array}{l}\text { Anadenanthera colubrina (Vell.) Brenan var. Cebil } \\
\text { (Griseb.) Altschul }\end{array}$ & Angico vermelho & 14 & 9,10 \\
\hline Bauhinia cheilantha (Bong.) Steud & Mororó & 164 & $1,2,3,4,5,6,7,8,9,10,11$ \\
\hline $\begin{array}{l}\text { Libidibia ferrea (Mart. ex Tul.) L.P.Queiroz var. } \\
\text { ferrea }\end{array}$ & Jucá, Pau ferro & 1 & 6 \\
\hline Mimosa caesalpiniifolia (Benth.) & Sabiá & 102 & $2,3,8,9,10$ \\
\hline Mimosa ophthalmocentra Mart. ex Benth. & Jurema de imbira & 159 & $2,4,5,6,7,8,10,11$ \\
\hline Mimosa tenuiflora (Willd.) Poir. & Jurema preta & 68 & $2,3,4,5,7,11$ \\
\hline Piptadenia stipulacea (Benth.) Ducke & Jurema branca & 116 & $1,2,3,4,8,9$ \\
\hline $\begin{array}{l}\text { Cenostigma pyramidale (Tul.) E. Gagnon \& } \\
\text { G.P.Lewis var pyramidale }\end{array}$ & Catingueira & 124 & $1,2,3,5,6,7,8,9,10$ \\
\hline $\begin{array}{l}\text { Malvaceae } \\
\text { Pseudobombax marginatum (A.St.-Hil.) A. Robyns }\end{array}$ & Embiratanha & 3 & 7,10 \\
\hline \multicolumn{4}{|l|}{ Oleaceae } \\
\hline Ximenia americana $\mathrm{L}$. var. & Ameixeira & 12 & $2,10,11$ \\
\hline $\begin{array}{l}\text { Mortas } \\
\end{array}$ & & 138 & $1,2,3,4,5,6,7,9,10,11$ \\
\hline Total & & 1,680 & \\
\hline
\end{tabular}


The diameter distribution followed the inverted "J" shape, common in uneven-aged forests, where the highest number of individuals is concentrated in the first two diametric classes, representing $89.16 \%$ of the inventoried individuals for this study (Figure 2). This result shows that even after years of irrational harvesting for power supply in the calcination process, among other uses, the areas have a high resilience.

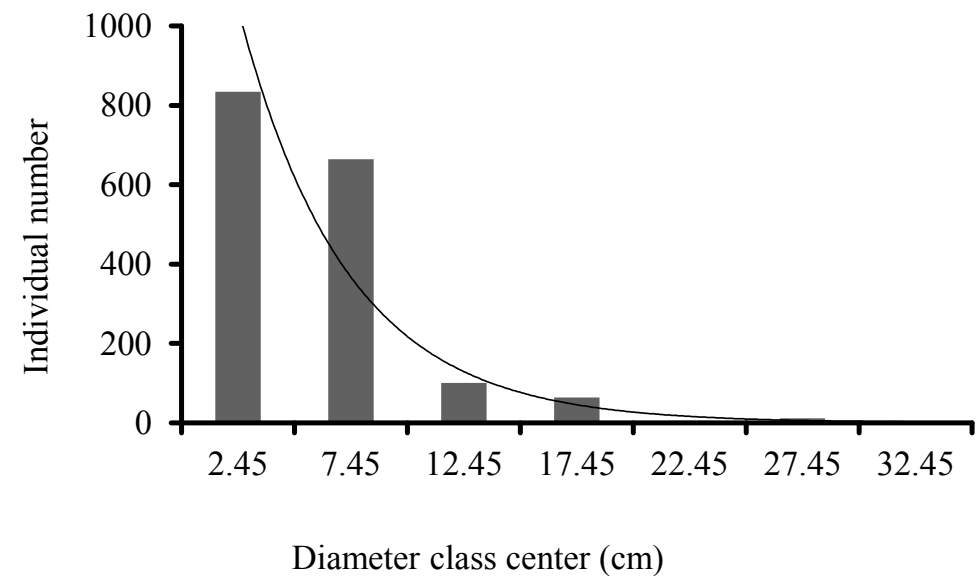

Figure 2. Distribution of the sampled individuals by diameter class in the forest management area.

As shown in Figure 2, there was a substantial number of individuals in the first two class centers, and from the second to the third class centers $(7.45$ and $12.45 \mathrm{~cm})$, there was an abrupt decrease $(84.9 \%)$. These results indicate that a reduced number of older individuals occurs in relation to the size of the size. However, these values appear higher when compared to other areas, such as in the study by Medeiros et al. (2018), who reported only $67 \%$ of individuals in the first three diametric classes.

According to Guedes et al. (2012), the higher concentration of individuals in the smallest diameters classes is characteristic of uneven-aged forests, indicating the potential for natural regeneration in the community. Santana and Souto (2006) claimed that areas with a high number of individuals in the smallest diameter classes are frequent in the Caatinga, which may be a strategy for the forest to recover after anthropic interventions and long periods of drought.

Conversely, the distribution of the basal area by the center of diameter classes showed a nonmonotonic manner, with the highest values found in the first three centers of diametric classes, representing $74.44 \%$ of the entire basal area. The basal area distribution followed the inverted "J" shape, as the number of individuals, indicating a regenerating community (Figure 3 ).

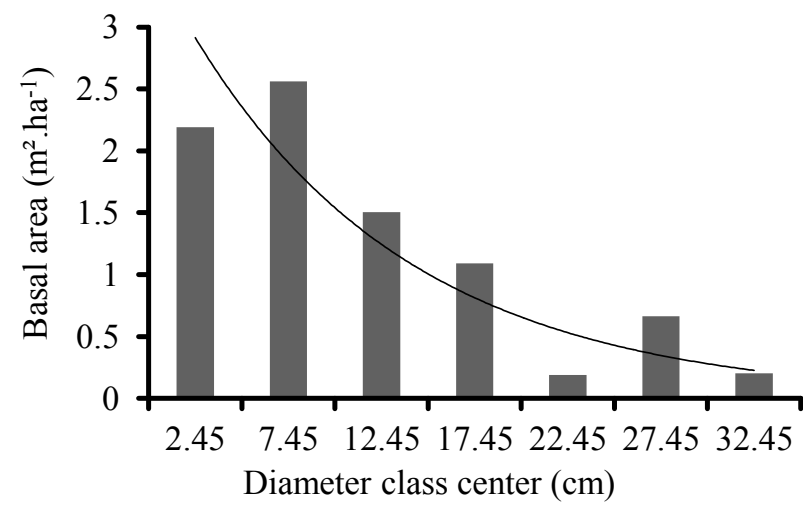

Figure 3. Distribution of the basal area by diameter class in the forest management area. 
Comparing the diameter distributions (Figures 2 and 3), there is a small number of older individuals than the new ones (Figure 2). However, old individuals had higher sectional areas, resulting in substantial absolute dominance in the largest centers of diametric classes, which may correspond to matrix trees.

Although the total basal area was low (7.0499 $\left.\mathrm{m}^{2} \mathrm{ha}^{-1}\right)$, this value does not deviate from the standard for dry forest areas in semi-arid environments. Areas with low human impact tend to have a higher basal area $(\mathrm{G})$, as reported by Moreira (2014), who obtained a basal area of $9.977 \mathrm{~m}^{2} \mathrm{ha}^{-1}$ in an area of the Caatinga located in the municipality of São José de Espinharas, state of Paraíba. In a similar study, Diniz (2011) estimated a basal area with twice $\left(14.651 \mathrm{~m}^{2} \mathrm{ha}^{-1}\right)$ the value found in this study in a Caatinga area located in Diamante, state of Paraíba.

The estimated coefficients $\beta 0$ and $\beta 1$ for the Meyer model were $\beta 0=7.464229126$, and $\beta 1=$ 0.2092553462. After estimating the De Liocourt quotient " $\mathrm{q}$ " for basal area and obtaining the actual volume based on the center of the maximum diameter class $(D \max =32.45 \mathrm{~cm}), \beta 0$ and $\beta 1$ were recalculated (Table 2).

Table 2. Values of the $\beta_{0}$ and $\beta_{1}$ coefficients for basal area and remaining actual volume in the Caatinga area under forest management.

\begin{tabular}{cccc}
\hline $\mathrm{G} \mathrm{m}^{2} \mathrm{ha}^{-1}$ & Remaining basal area $\left(\mathrm{m}^{2}\right)$ & $\beta_{0}$ & $\beta_{1}$ \\
\hline & 4.44 (reduced by $40 \%)$ & 6.564174924 & -0.17 \\
7.0499 & 3.52 (reduced by 50\%) & 5.863664107 & -0.14 \\
& 2.82 (reduced by 60\%) & 5.072380072 & -0.11 \\
\hline $\mathrm{V} \mathrm{m}^{3} \mathrm{ha}^{-1}$ & Actual remaining volume $\left(\mathrm{m}^{3}\right)$ & $\beta_{0}$ & $\beta_{1}$ \\
\hline & 5.29 (reduced by $40 \%)$ & 6.787655163 & -0.17 \\
& 4.40 (reduced by $50 \%)$ & 6.104046954 & -0.14 \\
& 3.52 (reduced by $60 \%)$ & 5.363928222 & -0.11 \\
\hline
\end{tabular}

The following De Liocourt quotient "q" values $2.3,2.0$, and 1.7 were randomly assigned to both the remaining basal area and the actual volume for all scenarios. Souza et al. (2013) tested combinations of $\mathrm{BDq}$ for five commercial tree species, in a phytophysiognomy different from that of this study, in the state of Amapá. The authors observed that, given the Dmax to be explored, the "q" value of 1.5 is recommended to remove individuals in the first four diametric classes, which makes the less harvested classes suitable for management. Therefore, the authors stated that it is more feasible to use a $\mathrm{q}>2$ to enhance regeneration and to explore a higher number of individuals in the suited classes for management. However, the ratio of 1.7 did not result in a deficit of trees in the diametric classes.

Using the "q" values, new distributions of the number of stems by diameter class were established for the remaining values and the harvest estimates. Table 3 shows the reduction of $40 \%$ (Scenario 1), $50 \%$ (Scenario 2), and 60\% (Scenario 3) of individuals based on the observed basal area.

In Scenario 1 , reducing $40 \%$ of the total basal area $\left(2.81 \mathrm{~m}^{2}\right.$ of $\left.\mathrm{G}\right), 82.68 \%$ of the individuals remained, which is equivalent to 1,379 stems. A harvest of $17.32 \%$ was estimated, which is equivalent to 301 stems within the diametric classes, with the most representative ones being 2.45 (123 stems), 7.45 ( 72 stems), and 12.45 (42 stems). In this scenario, the withdrawal of individuals from the diameter classes centers 22.45 and $32.45 \mathrm{~cm}$ is not indicated, as there will be a stem deficit in the harvest environment.

In Scenario 2, reducing $50 \%$ of G $\left(3.52 \mathrm{~m}^{2}\right.$ of $\mathrm{G}), 70.42 \%$ of the individuals remained, representing 1,182 stems. A harvest of $29.58 \%$ was estimated, which is equivalent to 498 stems within the diametric classes, with the most representative ones being 2.45 (251 stems), 7.45 (125 stems), and 12.45 (63 stems). In this scenario, the same pattern as for Scenario 1 was verified, where harvesting is not allowed for the diameter classes centers 22.45 and $32.45 \mathrm{~cm}$ due to the deficit of stems.

In Scenario 3, reducing $60 \%$ of $\mathrm{G}\left(4.22 \mathrm{~m}^{2}\right.$ of $\mathrm{G}), 50.54 \%$ of the individuals remained, representing 849 stems. A harvest of $49.46 \%$ was estimated, that is, 831 stems within the diametric classes, with the most representative ones being 2.45 (471 stems), 7.45 (205 stems), and 12.45 ( 89 stems). Similar to Scenarios 1 and 2, harvesting will not be allowed for the diameter class centers 22.45 and $32.45 \mathrm{~cm}$, as there will be a deficit of individuals. 
Table 3. Distribution of the number of individuals per hectare for the observed, estimated, and expected structure for the remaining trees, estimated by diameter class center. Basal area reduction of $40 \%$ (Scenario 1), De Liocourt quotient "q" = 2.3; $50 \%$ reduction (Scenario 2), " $q "=2.0$; and 60\% reduction (Scenario 3), " $q "=1.7$. Maximum diameter Dmax $=32.45$ $\mathrm{cm}$.

\begin{tabular}{|c|c|c|c|c|c|c|}
\hline \multirow{2}{*}{ Class center } & \multicolumn{2}{|c|}{ Observed value } & \multirow{2}{*}{$\begin{array}{c}\text { Estimated } \\
\text { value }\end{array}$} & \multirow{2}{*}{$\begin{array}{c}\text { Wanted } \\
\text { Scenario } 1 \\
\mathrm{~N}^{\mathrm{o}} \mathrm{ha}^{-1}\end{array}$} & \multirow{2}{*}{$\begin{array}{c}\text { Wanted } \\
\text { Scenario } 2 \\
\mathrm{~N}^{\circ} \mathrm{ha}^{-1}\end{array}$} & \multirow{2}{*}{$\begin{array}{c}\begin{array}{c}\text { Wanted } \\
\text { Scenario } 3\end{array} \\
\mathrm{~N}^{\circ} \mathrm{ha}^{-1}\end{array}$} \\
\hline & $\mathrm{N}^{\mathrm{o}} \mathrm{ha}^{-1}$ & $\mathrm{G} \mathrm{m}^{2} \mathrm{ha}^{-1}$ & & & & \\
\hline 2.45 & 834 & 2.151 & 1.042 & 711 & 583 & 363 \\
\hline 7.45 & 664 & 2.450 & 366 & 592 & 539 & 459 \\
\hline 12.45 & 100 & 1.093 & 129 & 48 & 37 & 11 \\
\hline 17.45 & 64 & 0.506 & 45 & 39 & 33 & 25 \\
\hline 22.45 & 5 & 0.189 & 16 & -10 & -11 & -12 \\
\hline 27.45 & 11 & 0.513 & 6 & 2 & 3 & 4 \\
\hline 32.45 & 2 & 0.203 & 2 & -3 & -2 & -1 \\
\hline Total & 1.680 & 7.0499 & 1.606 & 1.379 & 1.182 & 849 \\
\hline
\end{tabular}

As seen in Table 3, the largest class centers $(22.45,27.45$, and $32.45 \mathrm{~cm})$, when there was no deficit, had a limited number of trees $(27.45 \mathrm{~cm})$ for the three scenarios, indicating a lack of individuals with robust stems.

In a study carried out in the Caatinga area in the municipality of São José de Espinharas (Paraíba state), Moreira (2014) simulated selective logging with a "q" quotient of 1.94 and a $40 \%$ reduction (3.99 $\left.\mathrm{m}^{2} \mathrm{ha}^{-1}\right)$ of the total basal area $\left(9.97 \mathrm{~m}^{2} \mathrm{ha}^{-1}\right)$. The authors obtained 981 remaining individuals (43.10\% stems) and a harvest estimate of 1,294 stems, representing $56.1 \%$ of the trees. In the scenario with a $50 \%$ reduction in $\mathrm{G}\left(4.98 \mathrm{~m}^{2} \mathrm{ha}^{-1}\right)$, a harvest estimate of $64.2 \% \quad(1,458$ stems $)$ was observed, with $35.8 \%$ remaining trees ( 817 stems). In the scenario with a $60 \%$ reduction in $\mathrm{G}\left(5.98 \mathrm{~m}^{2}\right.$ $\mathrm{ha}^{-1}$ ), it was estimated that $28.7 \%$ of the stems remained (655 stems), with a harvest estimate of $71.2 \%$ (1,620 stems).

In another Caatinga area in the state of Paraiba, Diniz (2011) estimated a De Liocourt quotient "q" of 2.61 and simulated a reduction of $40 \%\left(6.5061 \mathrm{~m}^{2} \mathrm{ha}^{-1}\right)$ of the total basal area $(14.651$ $\left.\mathrm{m}^{2} \mathrm{ha}^{-1}\right)$, with a recommended $50.72 \%$ logging $(2,079.16$ stems $)$ of individuals $(4,100$ stems $)$. In the $50 \%$ selective logging $\left(7.3531 \mathrm{~m}^{2} \mathrm{ha}^{-1}\right)$, the harvest of $58.38 \%(2,393$ stems $)$ and the maintenance of $41.62 \%(1,707$ stems $)$ were recommended. In the $60 \%$ selective logging $\left(8.791 \mathrm{~m}^{2} \mathrm{ha}^{-1}\right)$, there was a harvest of $66.71 \%$ (2,735 stems).

The intervention plan per hectare showed that the diametric structure remained balanced for the first four class centers in the three scenarios, even after harvesting. Thus, it is believed that the recruitment rate (regeneration via seed or regrowth) of the species compensates for their mortality and/or removal.

Table 4 shows the estimated values after simulating a reduction of 40,50 , and $60 \%$ of the actual volume for Scenarios 1, 2, and 3. In Scenario 1 , reducing $40 \%\left(3.52 \mathrm{~m}^{3}\right)$ of the total volume $\left(8.8154 \mathrm{~m}^{3}\right), 76.79 \%$ of the stems remained. A harvest of $23.21 \%$ was estimated, which is equivalent to 402 stems within the diametric classes, with the most representative being 2.45 (165 stems), 7.45 (97 stems), and 12.45 (57 stems). The stem deficit occurred from the diameter class center of $22.45 \mathrm{~cm}$.

In Scenario 2, reducing $50 \%\left(4.40 \mathrm{~m}^{3}\right)$ of the total volume, $62.38 \%$ of the stems remained. A harvest of $37.62 \%$ was estimated, representing 635 stems within the diametric classes, with the most representative ones being $2.45,7.45$, and 12.45 , with 319 , 159, and 80 stems, respectively. The stem deficit occurred for the larger diametric class centers.

In Scenario 3, reducing $60 \%\left(5.29 \mathrm{~m}^{3}\right)$ of the $\mathrm{Vt}, 38.10 \%$ of the stems remained. A harvest of $61.90 \%$ was estimated, representing 1,043 stems within the diametric classes, with the first wo classes being he most representative ones with 846 stems. When comparing Scenario 3 for $G$ and actual volume, we observed an unusual deficit of trees $(-11)$ for the third class center $(12.45 \mathrm{~cm})$. A stem deficit was also calculated for the last three class centers $(22.45 ; 27.45$ and 32.45$)$.

As seen in the different logging intensities for the respective scenarios (Tables 3 and 4), the technical importance of the BDq method in the managed areas is highlighted. The study allows for a long-term analysis of sustainable harvesting, ensuring regularity and stability in the demand for woody stems in conjunction with the maintenance of the dynamic forest processes.

The low number of stems in the largest diameter class centers is justified since there was a significant number (406) of small individuals inventoried in the area (Aspidosperma pyrifolium, Croton blanchetianus, Bauhinia cheilantha, Mimosa caesalpiniifolia, Mimosa ophthalmocentra, Piptadenia stipulacea, and Cenostigma pyramidale), spatially distributed with a shrub species (Combretum leprosum). Consequently, it is suggested that the largest trees, with higher importance, become more vulnerable to irrational harvesting, requiring technical and scientific prolific studies that allow the occurrence of dynamic processes. 
Table 4. Distribution of the number of individuals for the observed, estimated, and expected structure for the remaining trees estimated by diameter class center. Actual volume reduction of $40 \%$ (Scenario 1), De Liocourt quotient " $\mathrm{q} "=2.3$; $50 \%$ reduction (Scenario 2), "q" $=2.0$; and 60\% reduction (Scenario 3), " $\mathrm{q} "=1.7$. Maximum diameter Dmax $=32.45 \mathrm{~cm}$.

\begin{tabular}{ccccccc}
\hline \multirow{2}{*}{$\begin{array}{c}\text { Class } \\
\text { center }\end{array}$} & \multicolumn{2}{c}{ Observed value } & $\begin{array}{c}\text { Estimated } \\
\text { value }\end{array}$ & $\begin{array}{c}\text { Wanted } \\
\text { Scenario 1 }\end{array}$ & $\begin{array}{c}\text { Wanted } \\
\text { Scenario 2 }\end{array}$ & $\begin{array}{c}\text { Wanted } \\
\text { Scenario 3 }\end{array}$ \\
\cline { 2 - 7 } & $\mathrm{N}^{\mathrm{o}}$ & $\mathrm{Vol} \mathrm{m}^{3}$ & $\mathrm{~N}^{\circ} \mathrm{ha}^{-1}$ & $\mathrm{~N}^{\circ} \mathrm{ha}^{-1}$ & $\mathrm{~N}^{\circ} \mathrm{ha}^{-1}$ & $\mathrm{~N}^{\circ} \mathrm{ha}^{-1}$ \\
\hline 2.45 & 834 & 0.8768 & 1.042 & 669 & 515 & 244 \\
7.45 & 664 & 3.7416 & 366 & 567 & 505 & 408 \\
12.45 & 100 & 1.4722 & 129 & 43 & 20 & -11 \\
17.45 & 64 & 0.7784 & 45 & 19 & 24 & 16 \\
22.45 & 5 & 0.1936 & 16 & -15 & -15 & -16 \\
27.45 & 11 & 1.3504 & 6 & 0 & -1 & -2 \\
32.45 & 2 & 0.4024 & 2 & -5 & -3 & -2 \\
\hline Total & 1.680 & 8.8154 & 1.606 & 1.278 & 1.045 & 637 \\
\hline
\end{tabular}

Since there was a low number of individuals in the highest diameter class centers, it is recommended that, in the long term, enrichment planting is carried out to enable recruitment and, consequently, rescue and maintain the stability of valuable species (Myracrodruon urundeuva, Cordia oncocalyx, Amburana cearensis, Anadenanthera colubrine, and Libidibia ferrea) in the area.

Periodic logging should occur in the smallest size classes, according to Souza and Souza (2005). Such an approach will allow a balanced diameter distribution within the classes, leading to a balanced forest throughout the logging cycle and the continuous availability of timber forest products.

In all three scenarios, the diameter distribution showed a deficit of trees in the highest class centers $(22.45,27.45$, and $35.45 \mathrm{~cm})$ in contrast with the lowest ones. These findings demonstrate that there is a balance to the lowest class and that adequate management can prevent the local extinction of species groups in the future. Our results agree with Felfili (1997), who affirms that species require large spatial and temporal scales to achieve the balance between mortality and recruitment. Thus, since the $\mathrm{BDq}$ method offers several logging alternatives, it allows a better harvest structure and, consequently, an optimized timber production.

\section{CONCLUSIONS}

Considering rational, sustainable harvesting and following the theoretical principles of dynamic processes, which will guarantee the long-term establishment of a balanced forest for this Caatinga area, logging cannot be conducted in the highest diameter class centers.

Scenario 3 resulted in the most effective results, since, in technical terms, it enables the harvest of a higher number of individuals. Consequently, it provides higher economic outputs while simultaneously ensuring natural regeneration.

\section{REFERENCES}

ALVARES, C. A. et al. Köppen's climate classification map for Brazil. Meteorologische Zeitschrift, 22: 711-728, 2013.

ALVES, J. J. A. Geoecologia da caatinga no semiárido do nordeste brasileiro. Climatologia e Estudos da Paisagem, 2: 58-71, 2007.

AMORIM, I. L.; SAMPAIO, E. V. S. B.; ARAÚJO, E. L. Flora e estrutura da vegetação arbustivoarbórea de uma área de Caatinga do Seridó, RN, Brasil. Acta Botânica Brasílica, 19: 615-623, 2005.

ARAÚJO, H. J. B. Acervo arbóreo das áreas sob manejo florestal comunitário do projeto de colonização Pedro Peixoto. 1. ed. Rio Banco, AC: Embrapa Acre, 2015. 49 p. (Embrapa Acre. Documento, 139).

ANGIOSPERM PHYLOGENY GROUP - APG IV. An update of the Angiosperm Phylogeny Group classification for the orders and families of flowering plants: APG IV. Botanical Journal of the Linnean Society, 181: 1-20, 2016.

BRASIL. REDE DE MANEJO FLORESTAL DA CAATINGA - RMFC. Protocolo de medições de parcelas permanentes. Disponível em: <http:// rmfc.cnip.org.br>. Acesso em: 05 set. 2019.

CALIXTO JÚNIOR, J. T.; DRUMOND, M. A. Estudo comparativo da estrutura fitossociológica de dois fragmentos de Caatinga em níveis diferentes de conservação. Pesquisa Florestal Brasileira, 34: 345 $-355,2014$.

CAMPOS, J. C. C.; LEITE, H. G. Mensuração florestal: perguntas e respostas. 4.ed. Viçosa, MG: Universidade Federal de Viçosa, 2013. 605 p.

CAMPOS, J. C. C.; RIBEIRO, J. C.; COUTO, L. 
Emprego da distribuição diamétrica na determinação da intensidade de cortes em matas naturais submetidas ao sistema de seleção. Revista Árvore, 7: 110-122, 1983.

DINIZ, C. E. F. Análise estrutural e corte seletivo baseado no método BDq em vegetação de caatinga. 2011. 114 f. Dissertação (Mestrado em ciências florestais: Área de Concentração em manejo florestal) - Universidade Federal de Campina Grande, Patos, 2011.

FELFILI, J. M. Diameter and height distributions in a gallery forest community and some of its main species in central Brazil over a six-year period (1985-1991). Revista Brasileira de Botânica, 20: 155-162, 1997.

GUEDES, R. S. et al. Caracterização florísticofitossociológica do componente lenhoso de um trecho de caatinga no semiárido paraibano. Revista Caatinga, 25: 99-108, 2012.

HOLANDA, A. C. et al. Estrutura da vegetação em remanescentes de caatinga com diferentes históricos de perturbação em Cajazeirinhas (PB). Revista Caatinga, 28: 142-150, 2015.

INSTITUTO BRASILEIRO DE GEOGRAFIA E ESTATISTICA - IBGE. Mapa de clima do Brasil. Rio de Janeiro: IBGE, 2002. Disponível em: ftp:// geoftp.ibge.gov.br/mapas/tematicos/mapas_murais $>$. Acesso em: 05 set. 2019.

INSTITUTO BRASILEIRO DE GEOGRAFIA E ESTATISTICA - IBGE. Mapa de vegetação do Brasil. Rio de Janeiro: IBGE, 2004. Disponível em: $\mathrm{ftp}: / /$ geoftp.ibge.gov.br/mapas/tematicos/ mapas_murais $>$. Acesso em: 05 set. 2019.

LEITE, J. A. N. et al. Análise quantitativa da vegetação lenhosa da Caatinga em Teixeira, PB. Pesquisa Florestal Brasileira, 35: 89-100, 2015.

LEMOS, J. R.; MEGURO, M. Estudo fitossociológico de uma área de Caatinga na Estação Ecológica (ESEC) de Aiuaba, Ceará, Brasil. Biotemas, 28: 39-50, 2015.

LIMA, R. B. et al. Volumetria e classificação da capacidade produtiva para Mora paraensis (Ducke) no estuário Amapaense. Scientia Forestalis, 42: 141 $-154,2014$

MARANGON, G. P. et al. Estrutura e padrão espacial da vegetação em uma área de Caatinga. Revista Floresta, 43: 83-92, 2013.

MEDEIROS, F. S. et al. Florística, fitossociologia e modelagem da distribuição diâmétrica em um fragmento de Caatinga em São Mamede-PB. Agropecuária Científica no Semiárido, 14: 85-95, 2018.

MEYER, H. A. Structure, growth, and drain in balanced uneven-aged forests. Journal of Forestry, 52: 85-92, 1952

MOREIRA, F. T. A. Florística, Fitossociologia e corte seletivo pelo método $\mathrm{BDq}$ em uma área de caatinga, no município de São José de Espinharas - PB. 2014. 59 f. Dissertação (Mestrado em Ciências Florestais: Área de Concentração em manejo florestal) - Universidade Federal de Campina Grande, Patos, 2014.

RODE, R. et al. Comparação da regulação florestal de projetos de fomento com áreas próprias de empresas florestais. Pesquisa Florestal Brasileira, 35: 11-19, 2015.

SANTANA, J. A. S.; SOUTO, J. S. Diversidade e estrutura fitossociológica da caatinga na Estação Ecológica do Seridó-RN. Revista Biologia e Ciência da Terra, 6: 232-242. 2006.

SANTOS, W. S. et al. Estudo fitossociológico em fragmento de caatinga em dois estágios de conservação, Patos, Paraíba. Agropecuária Científica no Semiárido, 13: 315-321, 2017.

SCHILling, A. C.; BATISTA, J. L. F. Curva de acumulação de espécies e suficiência amostral em florestas tropicais. Revista Brasileira de Botânica, 31: 179-187, 2008

SOTERO, J. P. et al. Floresta do Brasil em resumo: dados de 2007 a 2012. 1. ed. Brasília, DF: SFB, 2013. $188 \mathrm{p}$.

SILVA, P. H. et al. Optimal selective logging regime and $\log$ landing location models: a case study in the Amazon forest. Acta Amazonica, 48: 18-27, 2018.

SOUZA, D. R.; SOUZA, A. L. Emprego do método BDq de seleção após a exploração florestal em floresta ombrófila densa de terra firme, Amazônia oriental. Revista Árvore, 29: 617-625, 2005.

SOUZA, A. L.; SOARES, C. P. B. Floresta nativas: estrutura, dinâmica e manejo. 1. ed. Viçosa, MG: UFV, 2013. 322 p.

SOUZA, L. A. et al. Critérios de Seleção como subsídio ao manejo florestal na Amazônia. Método BDq. In: CONGRESSO AMAPAENSE DE INICIAÇÃO CIENTÍFICA DA UEAP, UNIFAP, IEPA E EMBRAPA AMAPÁ, $8^{\circ}$ MOSTRA DE TCC'S E $1^{\circ}$ EXPOSIÇÃO DE PESQUISA CIENTIFICA, 4., 2013, Macapá. Anais... Macapá: 
UEAP, 2013. p. 11

VERÍSSIMO, A.; PEREIRA, D. Produção na Amazônia Florestal: características, desafios e oportunidades. Parcerias Estratégicas, 19: 13-44, 2015.

ZAKIA, M. J. B; PAREYN, F. G. C.; RIEGELHAUPT, E. Equações de Peso e Volume para Oito Espécies Lenhosas Nativas do Seridó-RN. In: ZAKIA, M. J. B; PAREYN, F. G. C.(Eds.) Plano de Manejo Florestal para a Região do Seridó-RN. Natal, RN: Projeto PNUD/FAO/IBAMA/ BRA/87/007, 1988, v. 1, cap. 4, p. 1-94. 